\title{
A DYNAMIC VARIATION OF ROOT WATER UPTAKE IN DRIP IRRIGATED PADDY
}

\author{
M. ANGALEESWARI* \& V. RAVIKUMAR \\ Department of Irrigation and Drainage Engineering, Agricultural Engineering College \& Research Institute,
}

Kumulur, Trichy, Tamil Nadu, India

\begin{abstract}
Research on drip irrigated paddy is gaining importance due to the reason that, it reduces inefficient use of water and nutrients by optimum irrigation and fertigation scheduling. Modelling of root zone process is essential for drip irrigation management. Spatial and temporal changes in Root Water Uptake (RWU) distribution patterns is needed for estimating root zone parameters and also for obtaining average RWU location. It is useful for developing guidelines for soil water sensor placement. It is extremely challenging to measure RWU distribution directly from the field. In the present work inverse modelling was developed by solving Richards' equation inversely for estimating root water uptake. Spatial and temporal variation of volumetric water content was measured at the root zone using Time Domain Reflectometry (TDR) sensors. The dynamic variation of Root Water Uptake Distribution (UD) patterns in drip irrigated paddy was evaluated at 15 minutes interval. Temporal changes in the location of the average root water uptake and volumetric water content was evaluated for a period of 24 hours. The UD pattern during day time is completely different from the UD pattern at night. The changes in UD patterns are due to soil moisture content availability and root behaviours. It is noted that during day time the maximum $R W U$ was observed between dripper and plant locations and at night time the $R W U$ was observed away from the dripper location. The results from this work indicate that the root zone parameters are needed to be found out separately for day and night.

KEYWORDS: Paddy, Drip Irrigation, Root Water Uptake \& Inverse Modelling
\end{abstract}

Received: Dec 17, 2018; Accepted: Jan 08, 2019; Published: Jul 27, 2019; Paper Id.: IJASRAUG201936

\section{INTRODUCTION}

Paddy is the most important global food crop and it consumes more water for their cultivation under conventional irrigation method. Research on drip irrigation for paddy is important around the world because it reduces the inefficient use of water under conventional irrigation methods and it would meet the future demand. The paddy cultivation under drip irrigation uses $60 \%$ less water than conventional cultivation (Huaqi et al., 2002).

A better understanding of Root Water Uptake (RWU) is essential for improving irrigation and fertigation scheduling in drip irrigation(Green and Clothier, 1999). The RWU is a dynamic process influenced by many factors such as plant characteristics, cropping pattern, water content availability, soil hydraulic properties and environmental conditions respectively (Kumar et al., 2013). Generally, it is difficult to obtain RWU directly from the field experiments. Hence, modelling has become an attractive and viable option for evaluating root zone process. Most of the existing studies use the Richards equation to assess the soil water movement in the root zone by adding a sink term to the equation. The sink term is used to characterize root water uptake distributions in the root zone(Clausnitzer and Hopmans, 1994; Liao et al., 2016; Molz, 1981; Shankar et al., 2013; Zheng-feng et al., 2015). 
Several mathematical models have been developed to delineate RWU distributions(Gardner, 1991; Molz, 1981; Shankar et al., 2013). The distribution of root water extraction is determined by the root density distribution (Feddes et al., 1976; Musters and Bouten, 2000; Prasad, 1988; Wu et al., 1999). However, it is not an easy task to measure the root density distribution accurately and effectively. Therefore, it is difficult to determine the parameters of the root water uptake model. Afterwards, some studies have demonstrated success with the maximum likelihood or the genetic algorithm in optimizing RWU parameters. In this method, RWU patterns were assumed to follow certain distributions or functions, such as Bivariate Gaussian root distribution density function (Eugenio Coelho and Or, 1996), and exponential function (Musters and Bouten, 2000; Vrugt et al., 2001).

Since the distribution of RWU is very difficult to measure directly, it is important to develop approaches for estimating parameters in the RWU model. The distribution of soil water content contains information of RWU distribution which is easily measured by adopting advanced technologies like Time Domain Reflectometry (TDR). The higher spatial and temporal resolution of soil water content provides a better information on root zone process (Guderle and Hildebrandt, 2015).

In the present work, paddy crop was raised under drip irrigation. The spatial and temporal variation of soil water content is measured using TDR sensors. Using this data, RWU is estimated by solving Richard's equation inversely. The dynamic variation of Root Water Uptake Distribution (UD)patterns is computed at 15 minutes interval throws up much light on the temporal variation of RWU and UD patterns.

\section{MATERIALS AND METHODS}

\subsection{Field Description}

In this experiment CO51 cultivar rice was planted. Spacing between crop rows is alternately $20 \mathrm{~cm}$ and $40 \mathrm{~cm}$. Inter row spacing between plants is $10 \mathrm{~cm}$. One drip lateral per two crop rows was installed with a lateral spacing of $60 \mathrm{~cm}$. The dripper spacing in lateral is $30 \mathrm{~cm}$ and dripper discharge rate is 4 litres per hour (Figure 1). The operating pressure of the drip system was maintained at $10 \mathrm{~m}$ of the water column. The irrigation was scheduled by dual crop coefficient approach using meteorological data.
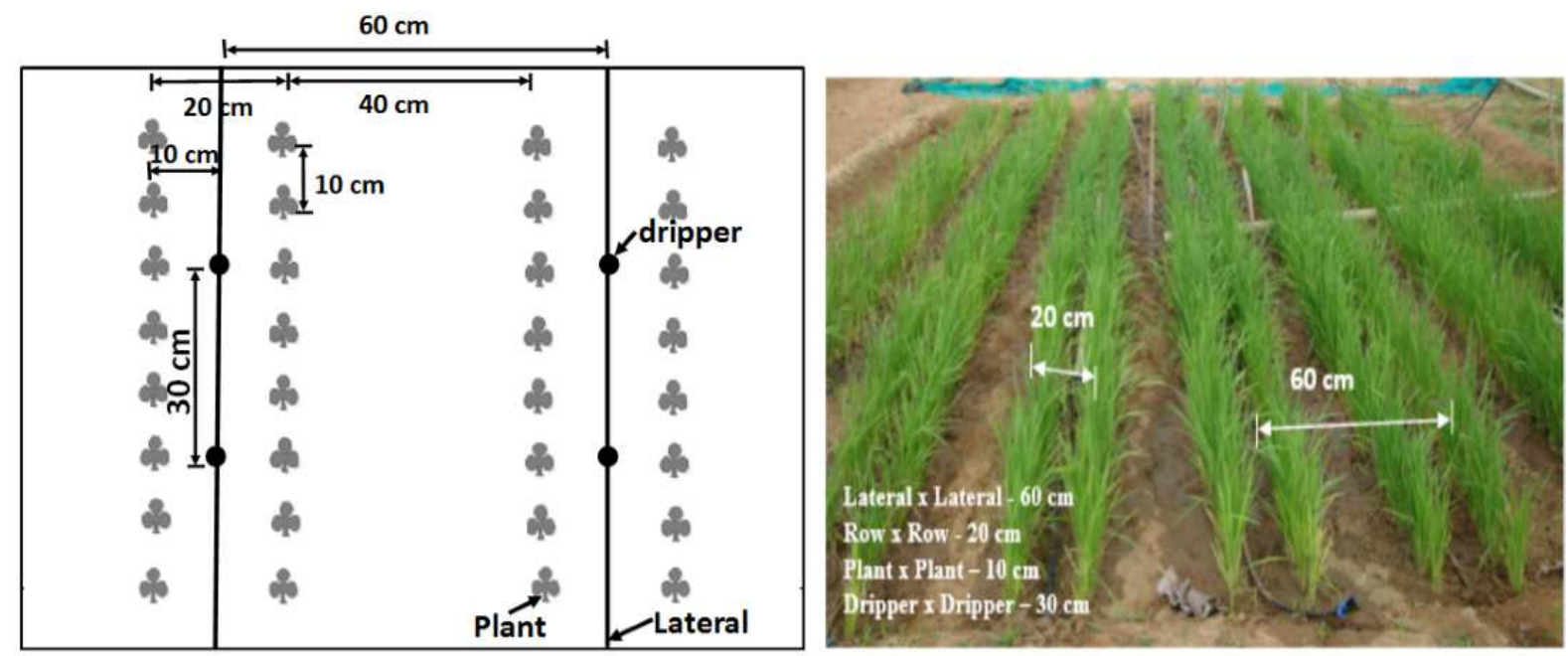

Figure 1: Layout of Experimental Plot 


\subsection{Soil Moisture Content Measurements}

The sensored volume of soil is divided into 15 numbers of cells (Figure 2). Notation $\mathrm{C}_{\mathrm{i}, \mathrm{j}}$ is used for addressing a cell where $\mathrm{i}$ is in horizontal and $\mathrm{j}$ is in vertical direction. Each cell is $30 \mathrm{~cm}$ length along the direction of crop rows (y direction) and has a depth of $15 \mathrm{~cm}$ ( $\mathrm{z}$ - direction). Horizontal dimension (x - direction) of each cell varies (Figure 2). Volumetric Water Content (VWC) is recorded at 15 minutes interval. The average VWC measured from each cell is assumed to occur at the centroid of each cell volume.

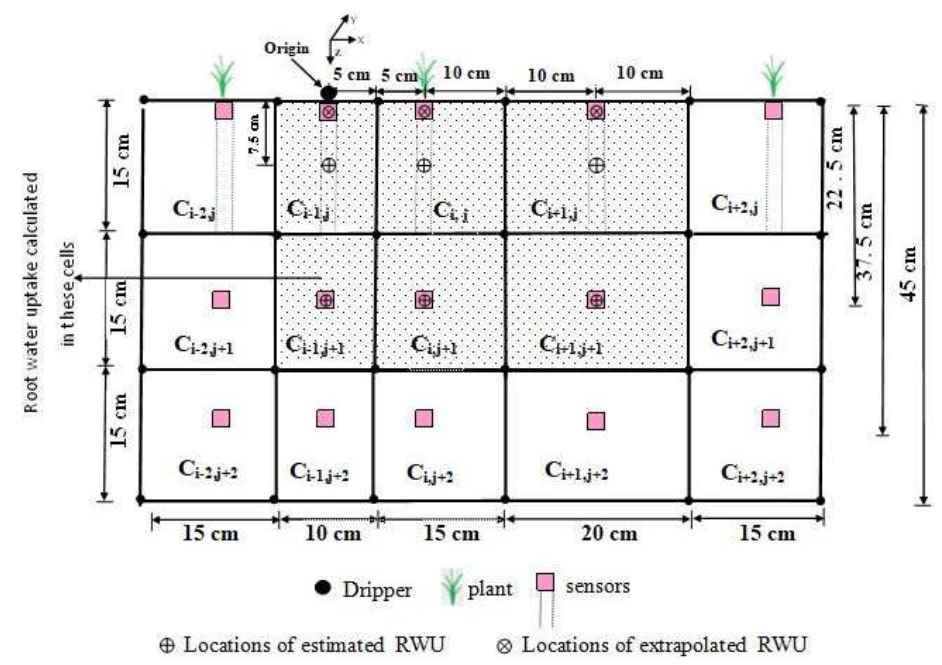

Figure 2: Sensors Location

\subsection{Estimation of Root Water Uptake using Volumetric Water Content data}

The Richards equation in two dimensions combined with a sink (U) term is used to describe soil water movement with RWU.

$$
\frac{\partial \theta}{\partial \mathrm{t}}=-\frac{\partial \mathrm{J}}{\partial \mathrm{z}}-\frac{\partial \mathrm{J}}{\partial \mathrm{x}}-\mathrm{U}
$$

where $\theta$ is the volumetric water content $\left(\mathrm{L}^{3} \mathrm{~L}^{-3}\right), \mathrm{J}$ is the volumetric flux density $\left(\mathrm{LT}^{-1}\right), \mathrm{t}$ is time $(\mathrm{T}), \mathrm{x} \& \mathrm{z}$ represent horizontal and vertical distances $(\mathrm{L})$ and $\mathrm{U}$ is a sink term, accounting $\mathrm{RWU}\left(\mathrm{L}^{3} \mathrm{~L}^{-3} \mathrm{~T}^{-1}\right)$.

The term RWU in Richards' equation which is unknown is found by solving Richards' equation inversely. For each cell, the RWU is estimated using the measured values of VWC of soil.

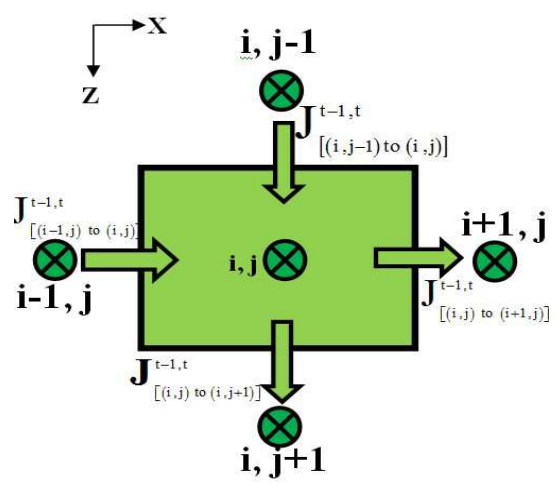

Figure 3: Flow Domain Discretized as Cells 
Finite difference formulation for Equation (1) is done based on the procedure available in Radcliffe and Simunek (2010). The two dimensional finite difference form of Richards equation to estimate RWU at $\mathrm{i}, \mathrm{j}^{\text {th }}$ cell for time $\mathrm{t}-1$ to $\mathrm{t}$ is as follows:

$$
\begin{aligned}
\mathrm{U}_{\mathrm{i}, \mathrm{j}}^{\mathrm{t}-1, \mathrm{t}}=-\frac{\theta_{\mathrm{i}, \mathrm{j}}^{\mathrm{t}}-\theta_{\mathrm{i}, \mathrm{j}}^{\mathrm{t}-1}}{\Delta \mathrm{t}}-\frac{\left[-\mathrm{K}\left(\dot{\theta}_{\mathrm{B}}\right)\left(\mathrm{h}_{\mathrm{i}, \mathrm{j}+1}^{\mathrm{t}-1, \mathrm{t}}-\mathrm{h}_{\mathrm{i}, \mathrm{j}}^{\mathrm{t}-1, \mathrm{t}}+\Delta \mathrm{z}\right)\right]-\left[-\mathrm{K}\left(\dot{\theta}_{\mathrm{T}}\right)\left(\mathrm{h}_{\mathrm{i}, \mathrm{j}}^{\mathrm{t}-1, \mathrm{t}}-\mathrm{h}_{\mathrm{i}, \mathrm{j}-\mathrm{t}}^{\mathrm{t}-\mathrm{t}}+\Delta \mathrm{z}\right)\right]}{\Delta \mathrm{z}^{2}} \\
-\frac{\left[-\mathrm{K}\left(\dot{\theta}_{\mathrm{R}}\right)\left(\mathrm{h}_{\mathrm{i}+1, \mathrm{j}}^{\mathrm{t}-\mathrm{t}}-\mathrm{h}_{\mathrm{i}, \mathrm{j}}^{\mathrm{t}-1, \mathrm{t}}\right)\right]-\left[-\mathrm{K}\left(\dot{\theta}_{\mathrm{L}}\right)\left(\mathrm{h}_{\mathrm{i}, \mathrm{j}}^{\mathrm{t}-1, \mathrm{t}}-\mathrm{h}_{\mathrm{i}-1, \mathrm{j}}^{\mathrm{t}-1, \mathrm{t}}\right)\right]}{\Delta \mathrm{x}^{2}}
\end{aligned}
$$

where $\Delta \mathrm{t}$ is the time interval $(\mathrm{T}), \Delta \mathrm{x} \& \Delta \mathrm{z}$ are the horizontal and vertical spatial discretization distances (L), $\mathrm{K}(\theta)$ is the unsaturated hydraulic conductivity $\left(\mathrm{LT}^{-1}\right)$, which is represented as a function of $\theta$; $\mathrm{h}$ is the soil water pressure head (L). The subscripts L,R,B \& T of $\theta$ represent flow occurring in the space left of $i, j$, right of $i, j$, bottom of $i, j$ and top of i, j respectively (Figure 3).

The analytical model describing the unsaturated retention and hydraulic conductivity functions used in this work is the van Genuchten - Mualem model (Van Genuchten, 1980). For the experimental plot, the van Genuchten - Mualem model parameters were estimated by conducting double ring infiltrometer test and by inverse modelling using Hydrus 1D(Namitha, 2017). The RWU for all the time periods and for all the cells is found out using Eq.2. The estimated RWU is assumed to occur at the centroid of the cells.

\subsection{Root Water Uptake Distribution (UD)}

The UD is defined as the ratio of RWU rate at a location to the total RWU rate of the root zone domain. UD was calculated for the period of 24 hours.

$$
\mathrm{UD}_{\mathrm{i}, \mathrm{j}}^{\mathrm{t}-\mathrm{t}, \mathrm{t}}=\frac{\mathrm{U}_{\mathrm{i}, \mathrm{j}}^{\mathrm{t}-\mathrm{t}}}{\sum_{\mathrm{i}, \mathrm{j}=1}^{\mathrm{N}} \mathrm{U}_{\mathrm{i}, \mathrm{j}}^{\mathrm{t}-\mathrm{t}, \mathrm{t}}}
$$

where $U D_{i, j}^{t-1, t} \& U_{i, j}^{t-1, t}$ are Root Water Uptake Distribution and Root Water Uptake rate respectively in $i$, $j^{\text {th }}$ location at time $\mathrm{t}-1$ to $\mathrm{t}, \mathrm{N}$ is total number of locations $(\mathrm{N}=9)$.

The RWU occurring at the surface of the soil is needed for determination of UD. The sensored VWC for the surface cells corresponds to the centroid of the surface cells. Therefore linear extrapolation is adopted to estimate the RWU values at the surface of the soil. UD for all the time periods and for all the cells is found out using Eq.3.

\section{RESULTS AND DISCUSSIONS}

Spatial and temporal distribution of RWU was estimated for a day $\left(70^{\text {th }}\right.$ day after sowing) using measured VWC in the root zone. The contour map of VWC and UD were developed at 15 minutes interval. The location of RWU concentration and uptake distribution pattern continuously changes at every interval of 1 to 3 hours in a day (Figure 4). The changes in UD patterns are due to availability of soil moisture content and root behaviours. At the initial period of after irrigation, the concentration of RWU at the dripper location of $15 \mathrm{~cm}$ depth and a maximum rate of RWU was found to 
be $0.04 \mathrm{~cm}^{3} \mathrm{~cm}^{-3} 15 \mathrm{~min}^{-1}$. The concentration of RWU remained at the same location for the 2 hours. Subsequently for the next four hours (10.45 am to $2.45 \mathrm{pm})$, the RWU occurred near the plant.

During initial period RWU concentration was observed within the depth of $15 \mathrm{~cm}$. As the time increases, the concentration of RWU shifts to another location where the soil moisture content is available for the plant uptake. The results at the time interval between $3 \mathrm{pm}$ to $6.15 \mathrm{pm}$ show that the pattern of UD shifted to another location which is away from the initial highest RWU location. More pronounced dynamic variation of UD pattern was observed at time interval between 12 am to 6.15 am. Four hours before next irrigation, the RWU intensity was observed at 20 to $30 \mathrm{~cm}$ distances from dripper of 15 to $30 \mathrm{~cm}$ depth even though the moisture content is available below the dripper. It occurred due to the maximum root development in this region. This maximum root development is contributed by paired row system of cultivation.

During day time the maximum RWU was observed between dripper and plant location of $15 \mathrm{~cm}$ depth whereas at night the RWU concentration shifted away from the dripper location (20 to $30 \mathrm{~cm}$ distance) below $15 \mathrm{~cm}$ depth. The estimated total RWU rate was 0.06 and $0.02 \mathrm{~cm}^{3} \mathrm{~cm}^{-3}$ day ${ }^{-1}$ at 0 to 15 and 15 to $30 \mathrm{~cm}$ depths respectively. The maximum amount of RWU occurred at a depth of 0 to $15 \mathrm{~cm}$. The UD pattern during day time is entirely different from the UD pattern at night. There was a continuous change was observed in UD patterns during night time especially at 12 am to 6.15 am but a minimum changes was observed during day time (Figure 4).

\section{Immediately after irrigation}
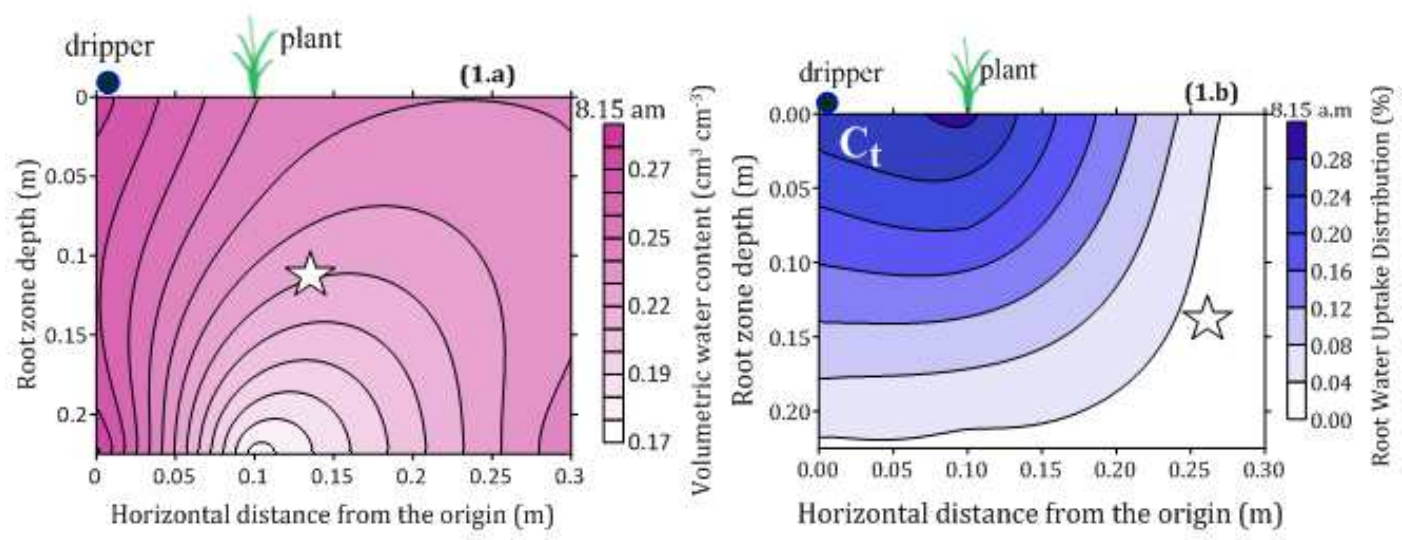

\section{After irrigation of 2 hours 30 minutues}
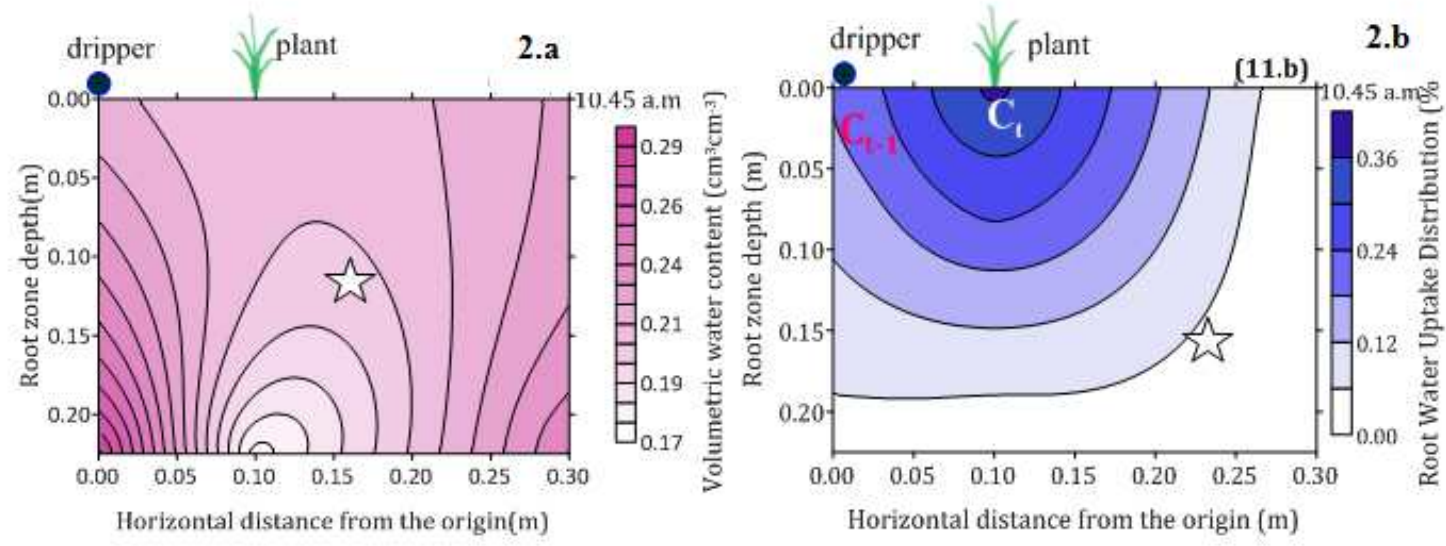


\section{Before next inigation}

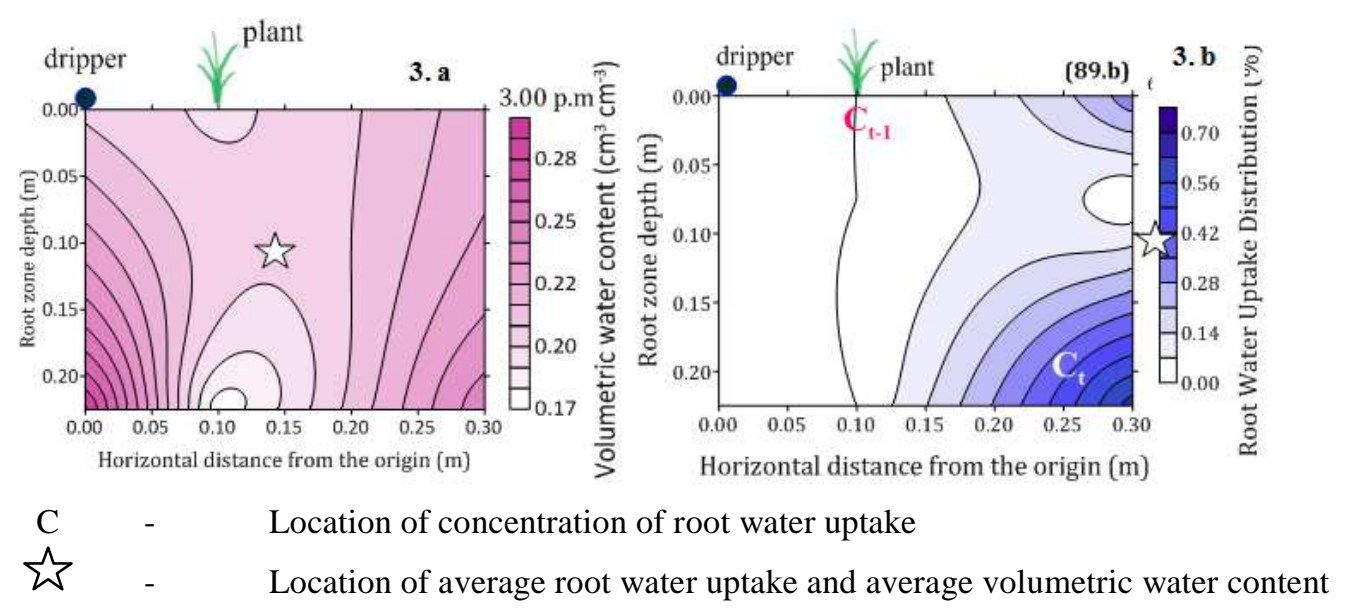

Figure 4: Volumetric Water Content and Uptake Distribution Pattern at 15 Minutes Interval

Spatial movement of RWU was evaluated for a day (Figures 5a \& b). At night the spatial movement of root water uptake concentration occurred 19 times where as in day time it occurred only 7 times (Table 1). For the four hours before next irrigation, a frequent spatial movement of root water uptake concentration was observed between the location of plant and 20 to $30 \mathrm{~cm}$ horizontal distances from dripper of 15 to $30 \mathrm{~cm}$ depth due to maximum root development in this region.
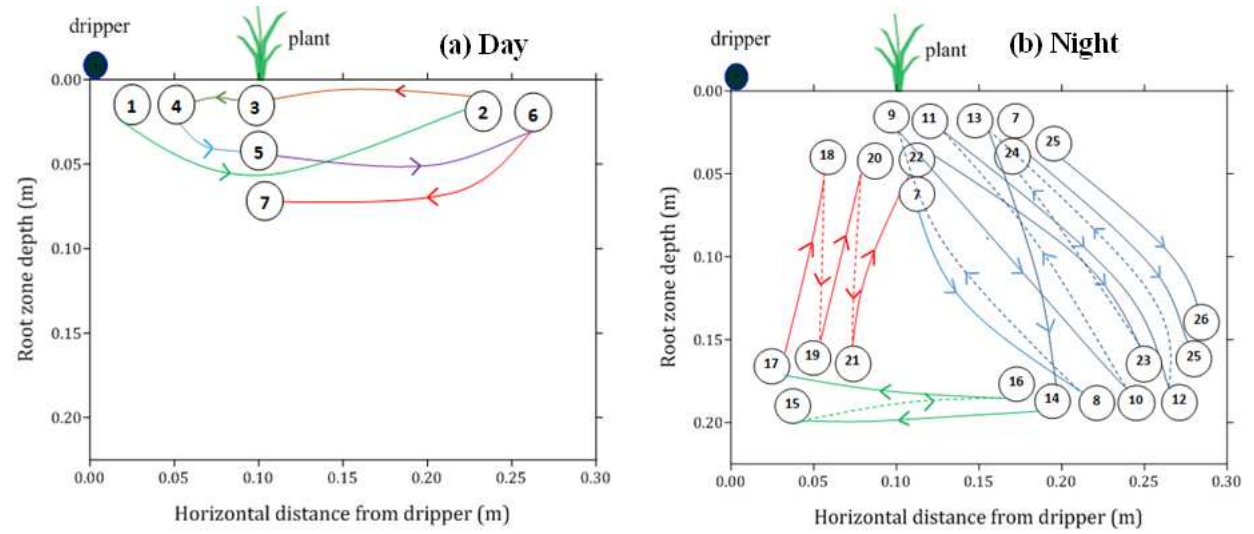

Figure 5: Spatial Movements of Root Water Uptake at Day and Night Time

Table 1: Spatial Movements of Root Water Uptake within a Day

\begin{tabular}{|c|c|c|c|c|c|}
\hline \multicolumn{2}{|c|}{ Time (h) } & \multirow{2}{*}{ Location } & \multicolumn{2}{c|}{ Time (h) } & \multirow{2}{*}{ Location } \\
\cline { 4 - 6 } From & To & & From & To & \\
\hline $8.00 \mathrm{am}$ & $8.15 \mathrm{am}$ & 1 & $1.45 \mathrm{am}$ & $2.00 \mathrm{am}$ & 13 to 14 \\
\hline $9.15 \mathrm{am}$ & $9.30 \mathrm{am}$ & 1 to 2 & $2.00 \mathrm{am}$ & $2.30 \mathrm{am}$ & 14 to 15 \\
\hline $9.30 \mathrm{am}$ & $9.45 \mathrm{am}$ & 2 to 3 & $2.30 \mathrm{am}$ & $2.45 \mathrm{am}$ & 15 to 16 \\
\hline $9.45 \mathrm{am}$ & $10.30 \mathrm{am}$ & 3 to 4 & $2.45 \mathrm{am}$ & $3.00 \mathrm{am}$ & 16 to 17 \\
\hline $10.30 \mathrm{am}$ & $2.45 \mathrm{pm}$ & 4 to 5 & $3.00 \mathrm{am}$ & $3.15 \mathrm{am}$ & 17 to 18 \\
\hline $2.45 \mathrm{pm}$ & $4.00 \mathrm{pm}$ & 5 to 6 & $3.15 \mathrm{am}$ & $3.30 \mathrm{am}$ & 18 to 19 \\
\hline $4.00 \mathrm{pm}$ & $8.30 \mathrm{pm}$ & 6 to 7 & $3.30 \mathrm{am}$ & $3.45 \mathrm{am}$ & 19 to 20 \\
\hline $8.30 \mathrm{pm}$ & $8.45 \mathrm{pm}$ & 7 to 8 & $3.45 \mathrm{am}$ & $4.00 \mathrm{am}$ & 20 to 21 \\
\hline $8.45 \mathrm{pm}$ & $9.15 \mathrm{pm}$ & 8 to 9 & $4.00 \mathrm{am}$ & $4.30 \mathrm{am}$ & 21 to 22 \\
\hline $9.15 \mathrm{pm}$ & $9.30 \mathrm{pm}$ & 9 to 10 & $4.30 \mathrm{am}$ & $5.00 \mathrm{am}$ & 22 to 23 \\
\hline $9.30 \mathrm{pm}$ & $10.15 \mathrm{pm}$ & 10 to 11 & $5.00 \mathrm{am}$ & $6.00 \mathrm{am}$ & 24 to 25 \\
\hline $10.15 \mathrm{pm}$ & $11.45 \mathrm{pm}$ & 11 to 12 & \multirow{2}{*}{$6.00 \mathrm{am}$} & \multirow{2}{*}{$6.15 \mathrm{am}$} & \multirow{2}{*}{25 to 26} \\
\hline $11.45 \mathrm{pm}$ & $1.45 \mathrm{am}$ & 12 to 13 & & & \\
\hline
\end{tabular}


Temporal changes in the locations of average RWU and VWC was evaluated for a day from the RWU contour map. Average location of RWU was assessed for every 15 minutes interval (Figures $6 \mathrm{a} \& \mathrm{~b}$ ). It is observed that the most of the average uptake location falls between 10 to $15 \mathrm{~cm}$ in horizontal and also in vertical direction from the dripper (Figure 6a). The average VWC location was also evaluated for similar time intervals and it falls between 8 to $12 \mathrm{~cm}$ in horizontal and 10 to $15 \mathrm{~cm}$ in vertical direction from the dripper (Figure 6b). The result shows that there is no significance difference between the average location of RWU and VWC.
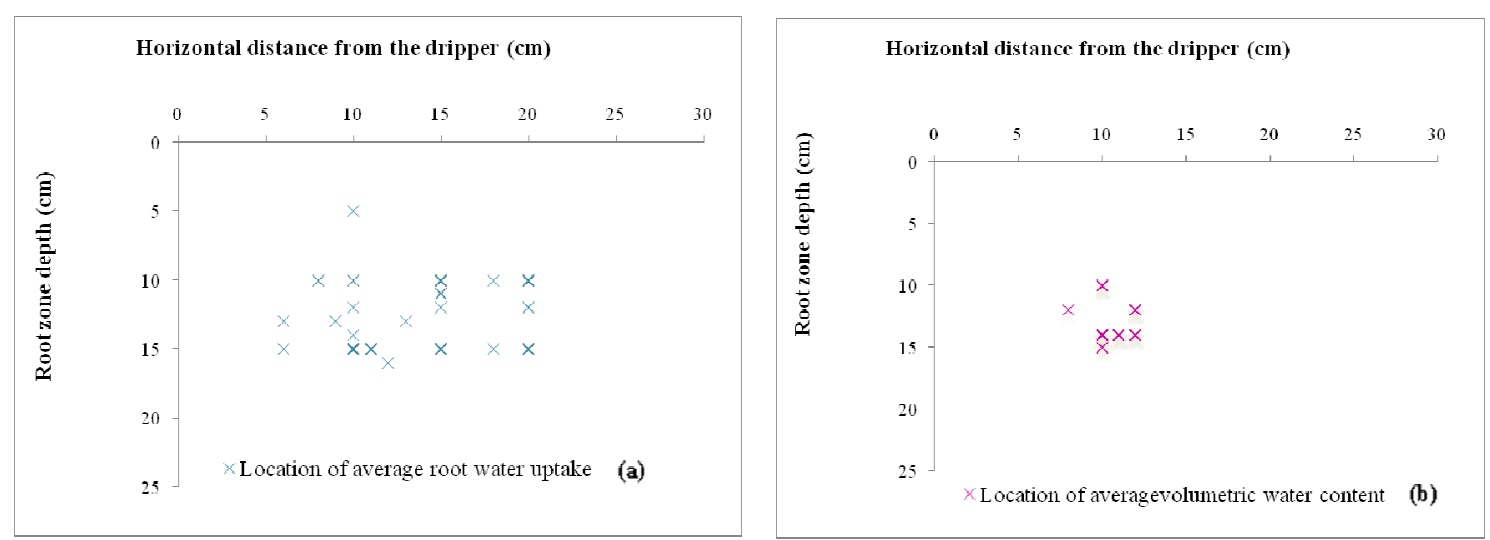

Figure 6: Spatial Variation of Average Root Water Uptake and Average Volumetric Water Content

\section{CONCLUSIONS}

Modelling of root zone process is useful in developing optimal irrigation management methodologies. Evaluation of the spatial and temporal changes in Root Water Uptake (RWU) distribution patterns is needed for estimating root zone parameters and also for obtaining average RWU location. In this work, the dynamic variations of Root Water Uptake Distribution (UD) pattern were evaluated by inversely solving Richards' equation. The UD pattern during day time is entirely different from the UD pattern at night. Spatial movement of RWU concentration was evaluated for a period of 24 hours. A higher spatial movement of RWU was observed during night time. The results from this work indicate that the root zone parameters are needed to be found out separately for day and night. Average location of the RWU and volumetric water content was evaluated and found that the average uptake location falls between $10-15 \mathrm{~cm}$ horizontal and vertical distances from dripper whereas the average volumetric water content falls between 8-12 cm horizontal and $10-15 \mathrm{~cm}$ vertical distance. Maximum concentration of RWU was observed near the plant $\left(i, j^{\text {th }}\right.$ cell). The obtained results help in supplying nutrients at the appropriate location. It is also useful for developing guidelines for sensor placement which is used for real time irrigation scheduling.

\section{REFERENCES}

1. Clausnitzer, V., Hopmans, J., 1994. Simultaneous modeling of transient three-dimensional root growth and soil water flow. Plant and soil 164, 299-314.

2. Eugenio Coelho, F., Or, D., 1996. A parametric model for two-dimensional water uptake intensity by corn roots under drip irrigation. Soil Science Society of America Journal 60, 1039-1049.

3. Feddes, R.A., Kowalik, P., Neuman, S.P., Bresler, E., 1976. FINITE DIFFERENCE AND FINITE ELEMENT SIMULATION OF FIELD WATER UPTAKE BY PLANTS / Simulation de la différence finie et de l'élément fini de l'humidité du sol utilisée par les plantes. Hydrological Sciences Bulletin 21, 81-98. 
4. Gardner, W.J.I.S., 1991. Modeling water uptake by roots. 12, 109-114.

5. Green, S., Clothier, B., 1999. The root zone dynamics of water uptake by a mature apple tree. Plant and Soil 206, 61-77.

6. Guderle, M., Hildebrandt, A., 2015. Using measured soil water contents to estimate evapotranspiration and root water uptake profiles-a comparative study. Hydrology and Earth System Sciences 19, 409-425.

7. Huaqi, W., Bouman, B., Zhao, D., Changgui, W., Moya, P., 2002. Aerobic rice in northern China: opportunities and challenges. Water-wise rice production. Los Baños (Philippines): International Rice Research Institute. p, 143-154.

8. Khalaf, R. M., \& Hassan, W. H. (2013). Evaluation of irrigation water quality index IWQI for Al-Dammam confined aquifer in the west and southwest of Karbala city, Iraq. International Journal of Civil Engineering IJCE, 23, 21-34.

9. Kumar, R., Jat, M.K., Shankar, V., 2013. Soil moisture dynamics modelling enabled by hydraulic redistribution in multi-layer root zone. Current Science, 1373-1382.

10. Liao, R., Yang, P., Wu, W., Ren, S., 2016. An inverse method to estimate the root water uptake source-sink term in soil water transport equation under the effect of superabsorbent polymer. PloS one 11, e0159936.

11. Molz, F.J., 1981. Models of water transport in the soil-plant system: A review. Water resources research 17, 1245-1260.

12. Musters, P., Bouten, W.J.J.o.h., 2000. A method for identifying optimum strategies of measuring soil water contents for calibrating a root water uptake model. 227, 273-286.

13. Namitha, M.R.a.R., V., 2017. Determination of Unsaturated hydraulic conductivity in field conditions through inverse modelling using Hydrus-ID. International Journal of Science, Engineering and Management 2, 2456-1304.

14. Patel, C. (2016). Market Analysis of Irrigation Pumps in Surat and Navsari Districts of Gujarat(Doctoral dissertation, Anand Agricultural University, Anand).

15. Prasad, R.J.J.o.H., 1988. A linear root water uptake model. 99, 297-306.

16. Radcliffe, D.E., Simunek, J., 2010. Soil physics with HYDRUS: Modeling and applications. CRC press.

17. Shashank, D. (2015). A comparative analysis of adoption of Nutrient Management Packages in Rice in Nalgonda district of Telangana State (Doctoral dissertation, Professor Jayashankar Telangana State Agricultural University, Rajendranagar, Hyderabad).

18. Shankar, V., Prasad, K.H., Ojha, C., Govindaraju, R., 2013. Optimizing Water Use in Irrigation-A Review. Journal of the Indian Institute of Science 93, 209-226.

19. Van Genuchten, M.T., 1980. A closed-form equation for predicting the hydraulic conductivity of unsaturated soils 1 . Soil science society of America journal 44, 892-898.

20. Vrugt, J., Hopmans, J., Šimunek, J., 2001. Calibration of a two-dimensional root water uptake model. Soil Science Society of America Journal 65, 1027-1037.

21. Wu, J., Zhang, R., Gui, S., 1999. Modeling soil water movement with water uptake by roots. Plant and soil 215, 7-17.

22. Zheng-feng, H., Po, L., Hui-xia, J., Gang-feng, W., Ke-feng, Z., 2015. Advances in Modeling Root Water Uptake-A Review. Metallurgical \& Mining Industry. 